\title{
THE PERCEPTION OF BRAZILIAN PORTUGUESE OPEN AND CLOSE MID VOWELS BY NATIVE RUSSIAN SPEAKERS
}

\author{
SMIRNOVA HENRIQUES, Anna ${ }^{1}$ * \\ SKRELIN, Pavel A. ${ }^{2}$ \\ EVDOKIMOVA, Vera V. ${ }^{2}$ \\ KACHKOVSKAIA, Tatiana $\mathrm{V}^{2}$ \\ BORREGO, Maria Cristina ${ }^{3}$ \\ PICCOLOTTO FERREIRA, Léslie ${ }^{4}$ \\ PICCIN BERTELLI ZULETA, Patrícia ${ }^{3}$ \\ RUSEISHVILI, Svetlana ${ }^{5}$ \\ MADUREIRA, Sandra ${ }^{1}$ \\ ${ }^{1}$ Laboratório Integrado de Análise Acústica e Cognição/ LIAAC, Programa de Estudos Pós-Graduados/ \\ PEPG em Linguística Aplicada e Estudos da Linguagem/ LAEL, Pontifícia Universidade Católica de São \\ Paulo/PUC-SP, Brazil \\ ${ }^{2}$ Department of Phonetics, Saint Petersburg State University, Saint Petersburg, Russia \\ ${ }^{3}$ Divisão de Educação e Reabilitação dos Distúrbios da Comunicação/ DERDIC, PUC-SP, São Paulo, \\ Brazil \\ ${ }^{4}$ Departamento de Teorias e Métodos em Fonoaudiologia - Programa de Estudos Pos-graduados em \\ Fonoaudiologia - PUC-SP \\ ${ }^{5}$ Departamento de Sociologia, Universidade Federal de São Carlos, Brazil.
}

\begin{abstract}
Studies on the perception of L2 sounds are relevant both to contribute to understanding language acquisition processes as well as to identifying learning difficulties and establishing strategies for training L2 language learners. There are plentiful studies on the perception of English speech sounds as L2, but not many on the perception of Brazilian Portuguese sounds as L2. This work contributes to filling this gap by investigating the perception of Brazilian Portuguese mid-open and midclose front vowels $/ \varepsilon /$ - /el, and mid-open and mid-close back vowels $/ \mathrm{/} / \mathrm{-} / \mathrm{l} /$ by a group of 103 native speakers of Russian, language which has no such contrasts. The control group is composed of 8 Brazilian native speakers. The perception test includes 30 trials distributed into three types of tasks: image identification, vowel identification, and word discrimination (8, 4 and 18 trials, respectively). It also contains a short sociolinguistic questionnaire. Our findings indicate that native Russian speakers have difficulties in discriminating the Brazilian Portuguese open/close mid vowel contrasts: the mean percentage of the correct answers in the Russophone group was 68\%, while in the Brazilian control group 99\%. The Russophones' perceptual ability in discriminating the open-close mid vowel contrasts has not been affected by either the kind of language instruction received or by their residence time in Brazil. These results have raised interesting issues on L2 speech sound acquisition and pronunciation instruction to be further pursued.
\end{abstract}

Keywords: Brazilian Portuguese as L2; Russian as L1; Perceptual Phonetics; Acoustic Phonetics; Brazilian Portuguese mid vowels.

*Corresponding author: palestrasrussas@gmail.com 


\section{Introduction}

Brazil has one of the largest migrant populations in South America (IOM World Migration Report, 2018, p. 80). According to the last published annual report of the Brazilian Observatory of the International Migration (OBMigra), from 2010 to 2017, the Federal Police registered 449,174 immigrants entering Brazil for long-term residence and 245,110 for short-term residence (Cavalcanti et al., 2018). However, the field of teaching Brazilian Portuguese as a Foreign Language is quite new; there are few specially trained language instructors, and access to didactic materials is limited (Adam et al., 2009; Amado, 2013; Furtoso, 2009; Lopez, 2016; Miranda \& Lopez, 2019). Until recently, even the extension courses of Portuguese as a Foreign Language in public Brazilian universities were mostly given by volunteers, mainly teachers of other foreign languages (Amado, 2013; Furtoso, 2009; Lopez, 2016; Farneda, 2019; Miranda \& Lopez, 2019). The current Brazilian language policy does not provide proper guidelines for the development of teaching Portuguese as a Foreign Language (Adam et al., 2009; Oliveira, 2019; Ribeiro, 2018). First (and for a long time the unique) Brazilian university offering an undergraduate course for language instructors teaching Portuguese as a Foreign Language was Universidade de Brasília; only in 2006, this course was introduced in Universidade Federal da Bahia, and in 2015, in Universidade Federal da Integração Latino-Americana and Universidade Estadual de Campinas (Farneda, 2019). The certificate of Proficiency in Portuguese for Foreigners (Certificado de Proficiência em Língua Portuguesa para Estrangeiros, CELPE-Bras) became mandatory for applying for Brazilian citizenship only in 2018 (Brasil, Portaria Interministerial $n^{\circ} 11,03 / 05 / 2018$ ). The fact that the place of Portuguese as a Foreign Language in the Brazilian education system has not been important up until recently might explain why the research interest in the acquisition/learning Brazilian Portuguese by non-native speakers has also been limited, despite a great number of studies on learning foreign languages by Brazilians (Castilho, 2004; Diniz de Figueiredo, 2018; Sant'Anna, 2008).

Our current research project is focused on native Russian speakers living in Brazil. We have recently created a database with 40 native Russian speakers living in São Paulo and begun to describe the specific features of their speech in Brazilian Portuguese and sociolinguistic profiles to characterize the Russian accent and factors that could influence its degree (Smirnova Henriques et al., in press). The Russophones came to Brazil for family, job, or study purposes. In our database, only $38 \%$ of the Russianspeaking immigrants reported to have studied Portuguese before moving to Brazil, and more than half of these relied on self-study (Smirnova Henriques et al., in press). In fact, there are few opportunities to study Portuguese in Russia: as described by Arefiev (2019), European Portuguese is taught as an undergraduate course only in nine Russian universities (from 965 universities available, http://stat.edu.ru/). Brazilian Portuguese courses, not considering small language schools, are available only in the Brazilian Cultural Centers of Moscow and Saint Petersburg (80 and 150 students in 2017, respectively), both supported by the Brazilian Embassy (Arefiev, 2019). At the present moment, only 15,000 people in Russia, out of 147 million (http://www.statdata.ru/russia), are considered to be proficient in Portuguese (Arefiev, 2019). This explains why most Russophone immigrants come to Brazil without any familiarity with Brazilian Portuguese phonetics. A report from 2010 about teaching Portuguese to native Russian speakers in Portugal also mentioned a large influx of immigrants from Eastern Europe who do not speak Portuguese, and emphasized an urgent need for language courses and development of materials for them (Head \& Semenova-Head, 2010).

When the Russophones included in our database were asked about their pronunciation difficulties in Brazilian Portuguese, more than $60 \%$ named difficulties in the production and/or perception of some sounds (Smirnova Henriques et al., in press). The most frequent difficulty identified by one-third of 
respondents was the differentiation of open and close mid vowels, as in the pair avólavô ("grandmother/grandfather"). The preliminary results obtained by a group of Audiology students who performed a perceptual analysis of homemade audio recordings received from 29 Russophone immigrants also pointed out difficulties in the distinction between Brazilian Portuguese open and close mid vowels as the most noticeable feature of their production (Vitoriano de Almeida et al., 2018).

In the present study, we investigate the perception of the Brazilian Portuguese open and close mid vowels by Russian Portuguese late bilinguals through an online test, performed by 103 respondents. All the Russian participants acquired Brazilian Portuguese as adults; 86 out of them are currently living in Brazil, including 56 from the São Paulo state. Eight Brazilian Portuguese speakers who answered the same test formed a control group.

Our main research question is: Do native Russian speakers discriminate mid vowel contrasts in Brazilian Portuguese? Our secondary questions are: Do language instruction (i.e., through formal versus informal instruction) and time residence (range: 3 months - 28 years) in Brazil interfere with the perception of the mid vowel contrasts? We have also monitored the information given by the participants on their self-evaluations. Our hypotheses are that Russophones have difficulties in discriminating the Brazilian Portuguese open/close mid vowel contrasts and that their perceptual ability in discriminating these contrasts is affected by kind of language instruction received and their time of residence in Brazil. These characteristics could be related to the quantity and quality of input defined as a crucial criterion for the establishment of a new phonetic category in L2 (Flege, 1995, 2007; Flege \& MacKay, 2011). However, the best way to define the quantity and quality of input is by means of a personal interview or the application of a detailed questionnaire such as the one we applied to construct our Russophone database (Smirnova Henriques et al., in press).

The aim of applying a perceptual test is to determine if Russophones living in Brazil perceive the difference between a pair of vowels which is non-contrastive in Russian. It is restricted to identify if the phonetic difference between the two vowels is recognized. If the vowels are discriminated by the Russophones, it means that mere exposure to the language in an immersive context is enough. If not, it means that awareness of the contrast and formal phonetic training are necessary.

In this research work, a phonetically based analysis of the discrimination of contrastive nonnative vowels is undertaken. Its main contributions are: focusing on Russian-Portuguese bilinguals; investigating if two vowel sounds of the L2 are assimilated into one as Flege (1995) predicts or if issues concerning the immersive context in which the bilinguals are inserted can help them to develop a phonological distinction. We also detail in the theoretical background section some contrasts between Russian and Brazilian Portuguese vowel sound inventories and survey some previous articles about the perception of Brazilian Portuguese vowels, published mainly by researchers who work with native speakers of English and Spanish.

The theorical foundation of our work is the phonetically oriented, language-specific model proposed by Flege (1995), whose emphasis is on the role of the perceptual cues for the discrimination of sounds. It is one of the most influential models of L2 sound perception for its comprehensiveness and for the relevant issues it arises such as equivalence classification of L1 and L2 sounds, the role of linguistic experience and time of residence in immersive contexts, and phonetic discrimination of L2 sounds.

This paper comprises an introduction to the phonological vowel systems of Brazilian Portuguese and Russian, a review of some studies addressing the issue of perception and production of mid vowel contrasts, some considerations of the theoretical framework adopted (the Speech Learning Model), a 
description of the material and method of the perceptual phonetic experiment, a presentation of the results of the experiment, their discussion, and concluding remarks.

\section{Theoretical background}

\subsection{The vowel system of Brazilian Portuguese}

Brazilian Portuguese has a seven-vowel phonological system /i, e, $\varepsilon, a, \rho, o, \mathrm{u} /$ in stressed position that is reduced to five vowels /i, e, a, o, $\mathrm{u} /$ in the pretonic and to three vowels $/ \mathrm{i}, \mathrm{a}, \mathrm{u} / \mathrm{in}$ the final posttonic position (Barbosa \& Madureira, 2015; Câmara Jr, 2007 [1970]; Barbosa and Albano, 2004). Portuguese

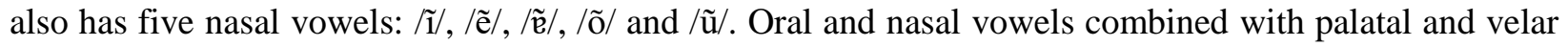
offglides form oral and nasal diphthongs.

Based on the position of the tongue, Brazilian Portuguese vowels are classified in three groups: front (/i, e,$\varepsilon /)$, back (/u, o, o/) and central (/a/); based on the tongue height, they are classified as high (/i, $\mathrm{u} /$ ), low $(/ \mathrm{a} /)$ and mid $(/ \mathrm{e}, \varepsilon, \rho, \mathrm{o} /)$; based on the position of the tongue and jaw vowels are described as open $(/ \varepsilon /, \mathrm{o} /, / \mathrm{a} /)$, and close $(/ \mathrm{i} /, / \mathrm{e} /, / \mathrm{o} / / \mathrm{u} /)$. Back vowels are rounded, and central and front vowels are unrounded.

Acoustically, Brazilian Portuguese vowels in stressed position are longer and more intense than those in posttonic position. Duration is not only the main acoustic correlate of the lexical stress in Brazilian (Massini, 1991) but as well as of the phrase stress (Barbosa, 2000). The phonetic quality of the vowels in tonic and posttonic position differs as shown by the frequencies of the resonances of the vocal tract, the formants (F1 and F2). The formant chart in Figure 1 (extracted from Pereyron \& Alves, 2019) shows the formant areas of seven vowels of Brazilian Portuguese in word stressed position.

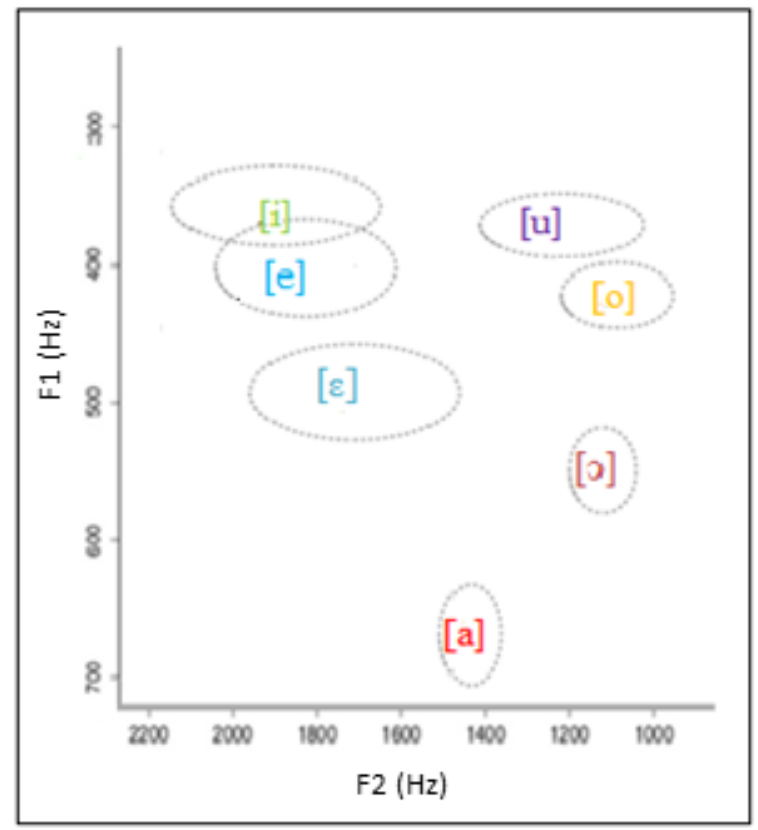

Figure 1: Acoustic characterization of the Brazilian Portuguese stressed vowels (extracted from Pereyron \& Alves, 2019). The ellipsis contours for F1 X F2 are based on data obtained from five Brazilian monolinguals, born, and residing in Porto Alegre. 
In this article, we focus on two open-close mid vowel contrasts: / $\varepsilon$, e/ and /o, o/. Open mid vowels have higher F1 frequencies that reflect the lower position of the tongue and jaw. The acoustic differences between the open and close mid vowels are visible in the F1 and F2 frequency displays in the spectrograms of Figure 2. The geometric means for F1 and F2 frequencies of the Brazilian Portuguese mid vowels are reported below on Table 1 (Barbosa \& Madureira, 2015, p. 305, 306). The values from other studies are similar (Díaz Granado, 2011; Escudero et al., 2009).

Table 1: The geometric means for F1 and F2 frequencies of the Brazilian Portuguese mid vowels as extracted from Barbosa \& Madureira (2015, p. 305, 306).

\begin{tabular}{c|c|c|c|c}
\hline \multirow{2}{*}{ Vowel } & \multicolumn{2}{|c|}{ Male } & \multicolumn{2}{c}{ Female } \\
\cline { 2 - 5 } & F1 (Hz) & F2 (Hz) & F1 (Hz) & F2 (Hz) \\
\hline$[\varepsilon]$ & 539 & 1660 & 678 & 2106 \\
\hline$[\mathrm{e}]$ & 364 & 1991 & 459 & 2343 \\
\hline$[\mathrm{o}]$ & 554 & 979 & 667 & 1117 \\
\hline$[\mathrm{o}]$ & 408 & 852 & 480 & 979 \\
\hline
\end{tabular}
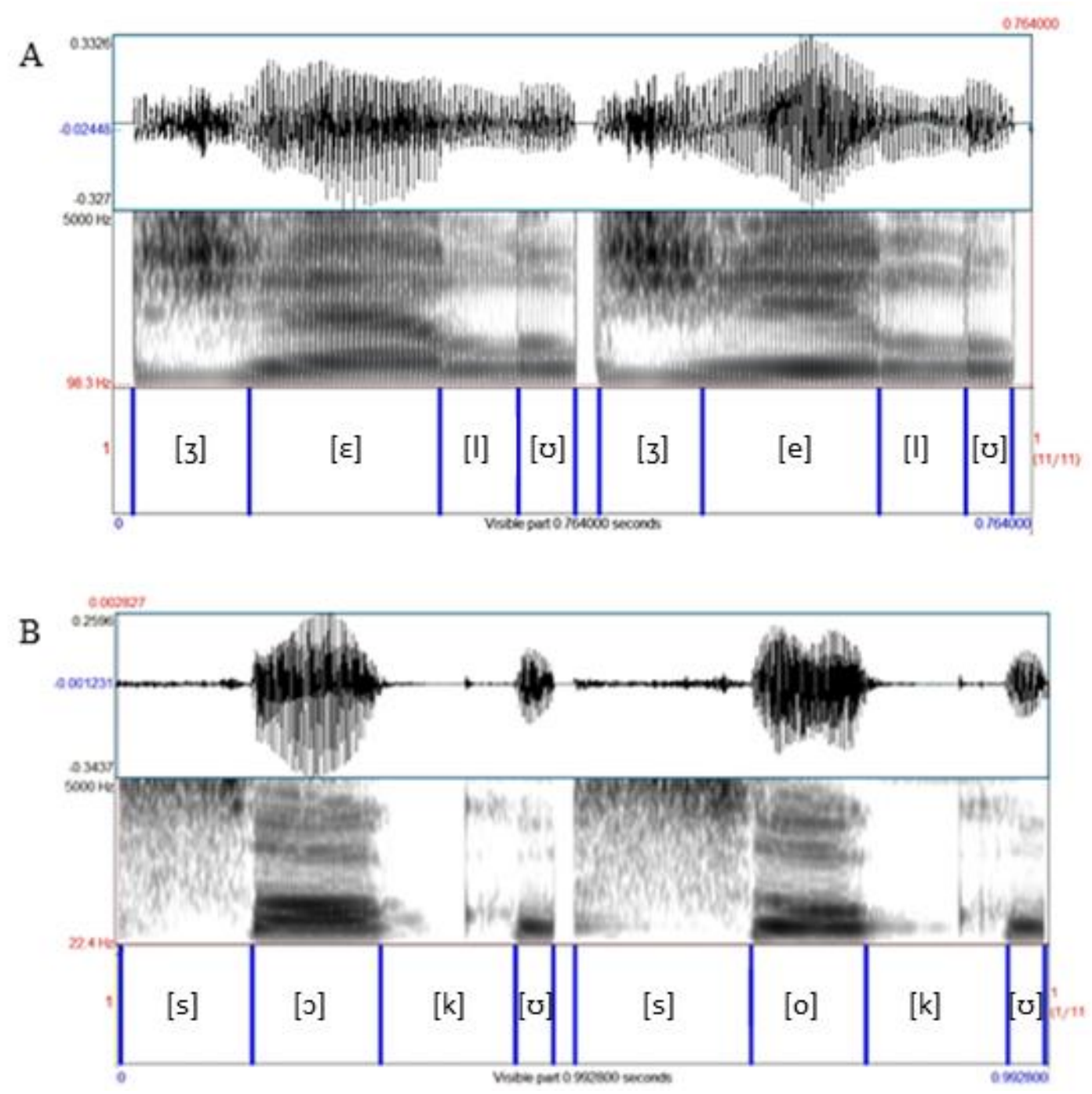
Figure 2: Spectrogram illustrations of words containing the Brazilian Portuguese mid front and back vowels. The spectrograms were made by the authors from recordings of one Brazilian female from São Paulo. A) On the left, the spectrogram corresponding to the verb form gelo ("(I) freeze") and on the right, to the noun form gelo ("ice"). B) On the left, the spectrogram of the production of the verb form soco and on the right the spectrogram of the noun form

$$
\text { soco ("blow"). }
$$

\subsection{The vowel system of Russian}

Russian has a simple six-vowel phonological system /i, e, i, a, o, u/ in stressed position (Scherba, 1974; Bondarko, 2009). The acoustic characteristics of these vowels are shown in Figure 3 (extracted from Evdokimova et al., 2020). These vowels contrast along the front-back, open-close, and roundedunrounded dimensions. Mid vowel phonemes are distinguished only by the front-back and by rounding dimensions and are phonologically transcribed as /e/ and /o/.

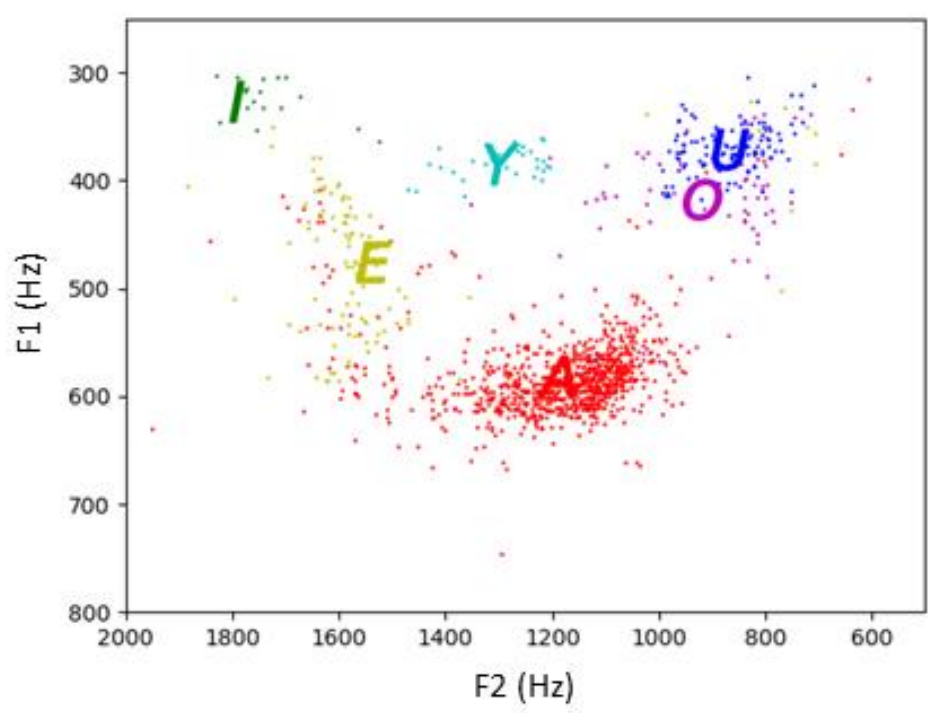

Figure 3: Acoustic characterization of the Russian stressed vowels. The formant chart is constructed on the data obtained from one male voice available in the CORPRES database (extracted from Evdokimova et al., 2020). In

Russia, it is common to use "Y" for the representation of /i/ using standard signs of the Latin alphabet.

In unstressed positions, according to the Leningrad phonological school, four vowel phonemes /i, $\dot{i}, \mathrm{u}, \mathrm{a} /$ are possible, but all of them undergo changes (Bondarko, 2009; Egorova, 2009). The vowels /i, $\dot{\mathrm{i}}$, $\mathrm{u} /$ become shorter and more centralized; but most of their quality is preserved. The vowel / $\mathrm{a} /$ changes into

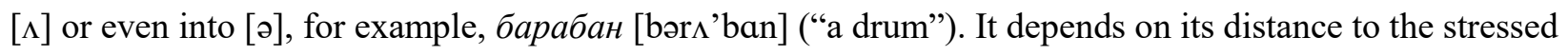
vowel and its location in the phonetic word (Bondarko, 2009; Egorova 2009; Kuznetsov, 1997). The vowels /e/ and /o/ have no unstressed allophones of their own (Bondarko et al., 1988). They alternate with the allophones of other vowels in unstressed syllables, for example, лес [lies] (“a forest”) and леса [lii'sa] ("forests"). In the present work, we focus on the stressed mid vowels and further describe their allophonic variation in detail.

The allophones of the Russian vowels /a, o, u, e/ are phonetically conditioned (Ordin, 2011). When these vowels are preceded by a palatalized ("soft") consonant, the palatal consonantal gesture 
extends to the onset of the vowels, modifying their onset qualities. Articulatorily the tongue dorsum is high in the palatal region, acoustically the second formant is raised and an /i/ like transitional gesture is perceived (Fig. 4). In Russian, most of the consonants can be palatalized; the palatalized consonants are interpreted as the ones having a secondary articulation as compared to the corresponding non-palatalized "hard" ones (Bondarko, 2005). Only six consonants do not form the "hard-soft" pairs. The features "hard" and "soft" are distinctive in Russian.
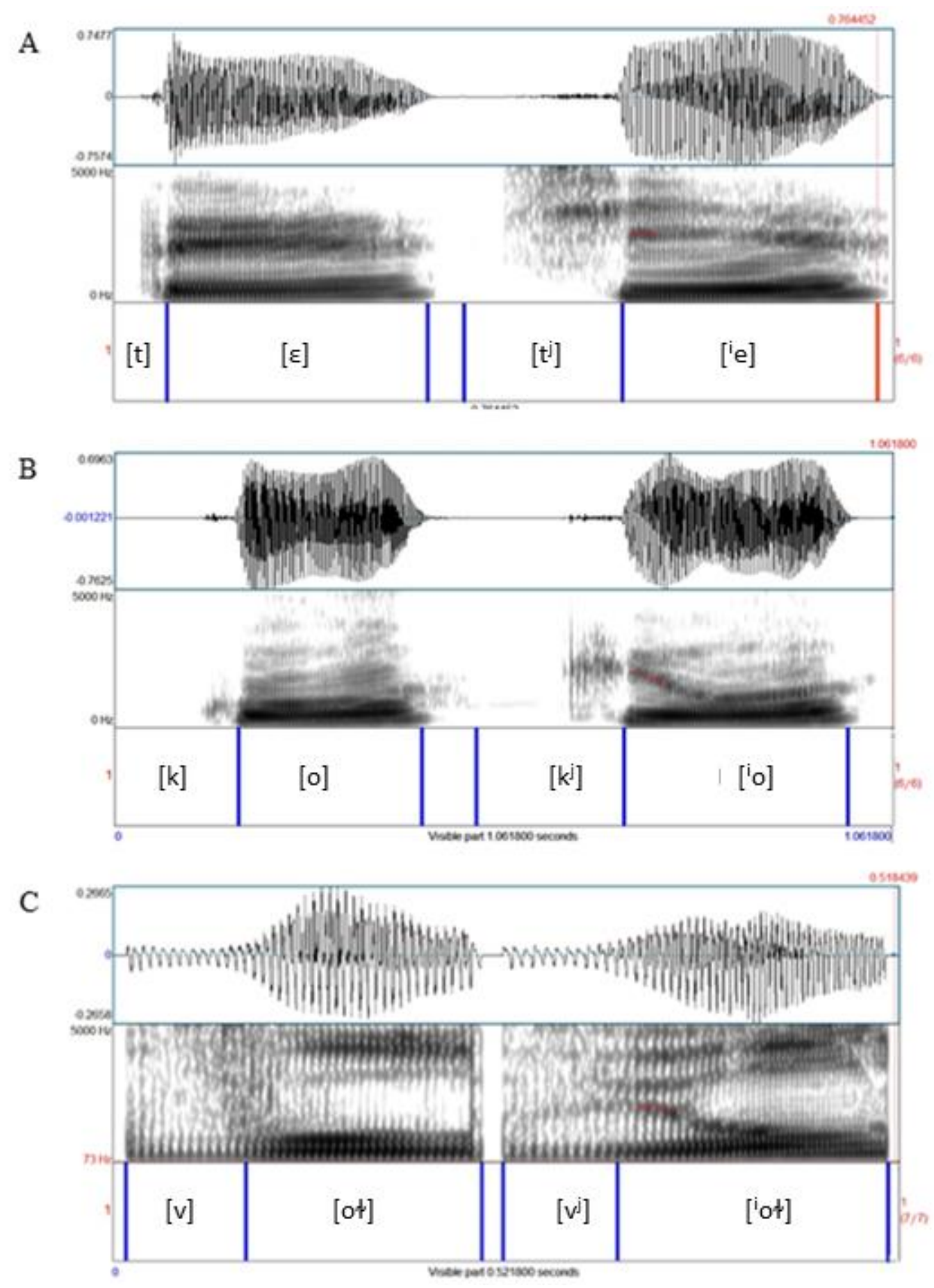
Figure 4: Spectrogram illustrations of the Russian mid vowels following a non-palatalized and a palatalized consonant. When the preceding consonant is "soft" (palatalized), the vowels get an /i/-transition. A-B) Spectrograms made by the authors, using the recordings of the Phonetic Fund of Russian Language, here a female speaker from Saint Petersburg (Bondarko, 1989). A) The vowel /e/ following a non-palatalized and palatalized consonant. B) The vowel /o/ following a non-palatalized and palatalized consonant. C) Spectrograms of two Russian words made by the authors using the recordings of the CORPRES database, here a female speaker (Volskaya et al., 2010). At left, the spectrogram of the word вол [vol] ("ox"). At right, the spectrogram of the word вёл [v ${ }^{j}$ ol] (Past Tense of the verb вести "to conduct"). The transition element is indicated by an * added to onset of the second formant.

The most frequent allophones of the vowels /a, o, $\mathrm{u}$ / occur following a non-palatalized consonant, for example, дама ['dama] ("lady"), дома ['doma] ("at home"), дума [“duma] ("a thought"). Following a palatalized consonant, these vowels are realized as much more fronted allophones compared to the main stressed allophones, as in $ә я д я$ [“ $\mathrm{d}^{\mathrm{j}} \mathrm{ad}^{\mathrm{j}} \Lambda$ ] (“an uncle”), тётя [“ $\mathrm{t}^{\mathrm{j}} \mathrm{t}^{\mathrm{j}} \Lambda$ ] (“an aunt”), тюльпан [ $\mathrm{t}^{\mathrm{j}} \mathrm{ul}^{\mathrm{j}}$ ' pan] (“a tulip"). The spectrograms of two syllables containing the vowel /o/ after a "hard" or a "soft" consonant are shown in Figure 4B. In some cases, the palatalization of precedent consonant could be a distinctive feature, for example, for вол [voł] (“ох") and вёл [vo] (Past Tense of the verb вести "to conduct") (Fig. 4C). For most speakers, /o/ is a mid back vowel [o], but it can be more open [0] for some speakers and in some words (Bondarko et al., 1988). Following a soft consonant, /o/ is centralized and raised to [ө], but all these variations are allophonic.

The most frequent allophone of the vowel /e/, [e], occur after a palatalized consonant (Fig. 4A), for example дети [' $\mathrm{d}^{\mathrm{j}} \mathrm{et} \mathrm{j}^{\mathrm{i}}$ ] ("children"). Its open-mid allophone $[\varepsilon]$ is realized after non-palatalized

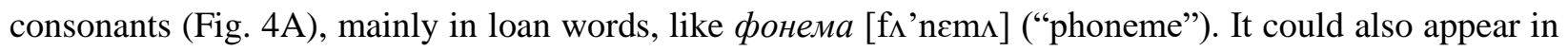

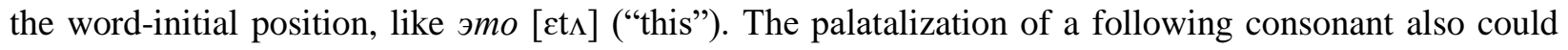
introduce an additional variation in the /e/ pronunciation. However, this variation is exclusively allophonic and never represents a phonemic contrast.

The central unrounded vowel [i] is also considered by many phoneticians as a contextual allophone of a close front unrounded vowel, which after soft consonants is realized as [i] and after "hard" consonants as [i]. However, /i/ and /i/ do occur contrastively in some minimal pairs, such as бblmb [bit'] ("to be") and бumb [bit'] ("to hit").

As the focus on this study is the perception of Brazilian Portuguese mid vowels by Russophones, it is worthwhile, for the sake of comparison, to consider the formant frequencies of the Russian mid vowels. The range of their frequencies are shown on Table 2 (extracted from Sorokin et al, 2009). The formant frequencies for two subjects are found in Kuznetsov (1997, p.109). They are: for /e/, one subject showed $\mathrm{F} 1=400$ and F2 $=2000$, another showed F1 $=500$ and F2 $=2250$; for /o/, one subject showed F1 $=400$ and F2 $=700$, another showed F1 $=500$ and F2 $=800$. This corresponds to the data on the formant charts from other authors (Bondarko, 1981).

Table 2: The range of the F1 and F2 frequencies of the Russian mid vowels as extracted from Sorokin et al., 2009.

\begin{tabular}{c|c|c|c|c}
\hline \multirow{2}{*}{ Vowel } & \multicolumn{2}{|c|}{ Male } & \multicolumn{2}{c}{ Female } \\
\cline { 2 - 5 } & F1 (Hz) & F2 (Hz) & F1 (Hz) & F2 (Hz) \\
\hline$[\varepsilon]$ & $320-530$ & $1450-2250$ & $350-600$ & $1800-2600$ \\
\hline$[\mathrm{e}]^{*}$ & $250-570$ & $1450-2250$ & $300-650$ & $2000-2950$ \\
\hline$[\mathrm{o}]$ & $300-750$ & $600-1400$ & $320-850$ & $600-1550$ \\
\hline
\end{tabular}


* the allophone [e] has an /i/-transition, so the formants should be measured in the stable part of the spectrogram after the F2 peak. The formant values alone are not representative for the characterization of the vowel and are used rarely.

The Old Russian language, spoken from the $10^{\text {th }}$ to $14^{\text {th }}$ century, had a more complex vowel system with some additional mid vowels and phonemic contrasts that were lost later (Vinokur, 2016). Currently, some of these contrasts are found in some rare dialects spoken by elderly people, such as in the speech of a small village called Leka: in 1992, Sappok et al. (1993) collected there speech samples from women aged 64-86 years old. This village has only 63 inhabitants and has been visited for linguistic research purposes in the $20^{\text {th }}$ century three times.

\subsection{Perception and production studies on open-close mid vowel contrasts}

The Brazilian Portuguese mid vowel system differs not only from the Russian one, as aforementioned, but from those of other languages such as Spanish (Díaz Granado, 2011; Allegro, 2010) in which close and open mid vowels do not contrast.

The works investigating the discrimination between minimal pair of words point to the fact that native speakers of languages which do not have the mid vowel phonemic contrasts, but do have mid open and close allophones, do not have better results in discriminating such contrasts in L2 than languages which do not have those allophones. Catalan, for instance, similarly to Portuguese, also has the openclose mid vowel contrasts, and these remain difficult for the native speakers of Spanish even if they began speaking Catalan as L2 as young children. Probably, these phonemic contrasts are phonetically less salient and this results in functional "deafness" to the contrast (Mora et al., 2011). It was observed that the more frequently Catalan was used, the less Spanish-like were productions of Catalan / $/$ / and /o/; the open mid vowels were produced less successfully by early learners of Catalan who continue using Spanish (Mora et al., 2015).

Difficulties in discriminating contrasts are also encountered by speakers of languages in which mid vowel contrasts exist but their allophones differ from the L2 language. The American English vowel system, for instance, distinguishes between a high mid vowel which is diphthongized, and a low mid vowel. However, as the American English and the Brazilian Portuguese low mid vowels belong to different phonetic entities, as far as the degree of openness is concerned, the speakers of American English are not able to reproduce these Brazilian Portuguese vowels (Díaz Granado, 2011).

The interference of the variable "time of residence" in perceiving not only mid vowel contrasts but all English vowel contrasts was investigated in Flege and Mackey (2004). They conducted four experiments. The first and second experiments involved Italian university students living in the USA for just three months of residence; the third group was formed by long-time Italian residents in the United States; and fourth experiment compared both groups: short and long-time residents. The results indicated that long-time residents who seldom used Italian performed better than those who frequently used Italian. This finding was interpreted by the authors as favouring the SLM hypothesis that "the capacity to establish new categories remain intact across life span". The results obtained by the author indicate that "time of residence" alone does not have a positive impact on improving vowel discrimination and that the amount of input matters a lot.

The works investigating the perception of the Brazilian Portuguese mid vowel contrasts are focused mainly on university learners of Brazilian Portuguese as L2. However, some research groups study bilinguals, immigrants, and even speakers of other languages with no knowledge of the Portuguese 
language. The results of some of these works, considering perception and production aspects, are reported in this section. They point to the relevance of studying the contrasts between close and mid vowels in Portuguese and discussing the factors that influence their perception by non-native speakers.

Simões and Kelm (1991) investigated the perception of minimal pairs by eight Brazilian Portuguese learners studying in the United States. Four of them were Spanish native speakers and four American native speakers. The Spanish native speakers scored $64 \%$ of the correct answers in the perception test for the front mid vowel contrast $/ \varepsilon /-/ \mathrm{e} /$ and $82 \%$ for the back mid vowel contrast / $/ \mathrm{J} / \mathrm{o} /$. The English native speakers got $89 \%$ of the correct answers for the front mid vowel contrast and $92 \%$ for the back mid vowel contrast. The percentages of correct discrimination reported by Allegro (2010) regarding a perception test applied to Argentinian students learning Portuguese in a University in Buenos Aires were lower: $53 \%$ for the front mid vowel contrast, and $46 \%$ for the back mid vowel contrast.

Kendall (2004) investigated the perception and production of Brazilian Portuguese mid vowels by twenty American learners of Brazilian Portuguese, ten beginners, and ten advanced. The advanced ones had lived in Brazil for nearly two years. The results indicated that both the beginning and the advanced learners had difficulty in discriminating the Portuguese close and open mid vowels. In the perception study, beginners scored $68 \%$ on $/ \varepsilon /-/ \mathrm{e} /$ and $70 \%$ on $/ \mathrm{o} / \mathrm{/o} /$; the advanced learners scored $78 \%$ for both pairs. In the production study, both beginners and advanced learners had difficulties with open vowels (scored $33 \%$ and $64 \%$ for [E]; $12 \%$ and $20 \%$ for [o], respectively, as evaluated by two Brazilian native speakers).

Díaz Granado (2011) investigated the perception and production of the Brazilian Portuguese mid vowels by two groups of native speakers of American English, one group with 7 learners of Brazilian Portuguese as L2 and the other 7 learners of Brazilian Portuguese as L3 with L2 Spanish. At the production level, in relation to the front mid vowel contrasts, the Brazilian Portuguese learners created a new single phonetic category that differed from those of English or Portuguese spoken by the native speakers. For the back mid vowels, the Brazilian Portuguese learners either did not differentiate the vowels or maintained a much smaller difference. At the perception level, Díaz Granado (2011) studied how the Brazilian Portuguese learners assimilate the two mid-front vowels of Portuguese to different English mid-front vowels: Portuguese / $\varepsilon /$ was assimilated to English $/ \varepsilon /$ in $90-95 \%$ of the cases and Portuguese /e/ was assimilated to English /e/ in 60-65\% of the cases.

Studies on vowel discrimination by non-native speakers with no knowledge of Portuguese were carried out by Elvin et al $(2014,2018)$. Their findings show that the most difficult vowel contrast was /o//u/, followed by the pair /e/-/i/. Discrimination between Brazilian Portuguese vowels / $/ \mathrm{e} /$ /e/ and between /o/-/o/ was found to be above 80\% accurate for Australian English and Iberian Spanish monolingual speakers. When the experiment involved the differentiation of both Brazilian and European Portuguese mid vowels by Californian English monolinguals and Spanish-English bilinguals, the scores were higher than $70 \%$.

Three works that focused on the production of the Brazilian Portuguese mid vowels by bilinguals in Brazil are: Mileski (2017), Machry da Silva (2015), and Pereyron \& Alves (2019). Mileski (2017) described the lowering of the tonic and pretonic mid vowels /e, o/ in speech productions of PortuguesePolish bilinguals living in Rio Grande do Sul. The vowel system of Polish does not have mid close vowels and their findings show that the elderly, who were used to speaking Polish frequently, tended to show higher rates of lowering the mid vowels. Machry da Silva (2015) studied 12 immigrants from Argentina and Uruguay, living in Brazil, and found that they were not able to pronounce the Brazilian Portuguese open mid vowels as Brazilian native speakers do. Pereyron \& Alves (2019) also focused on 
Portuguese-Spanish bilinguals and performed an acoustic analysis of their Brazilian Portuguese mid vowel productions. They compared the data obtained from Brazilians, Hispanic monolinguals and bilingual Hispanic speakers living in Southern Brazil; each group contained five participants. The participants were asked to read carrier sentences containing six words for each vowel, each sentence repeated three times, generating a total number of 18 tokens for each vowel. The researchers concluded that native Spanish speakers living in Brazil did not produce the open mid front and back vowels in Brazilian Portuguese. Their close mid vowels had different formant values in comparison to Hispanic monolinguals.

The languages involved in the research works on either the production or the perception of Brazilian mid vowel contrasts in the works by Simões \& Kelm (1991), Kendall (2004), Allegro ( 2010), Díaz Granado (2011), Feiden et al. (2014), Elvin et al (2014, 2018), Machry da Silva, (2015), Mileski (2017) and Pereyron and Alves (2019) are either English or Spanish.

To the best of our knowledge, no perception studies on the open-close contrast of the Brazilian Portuguese mid vowels have been carried out with native speakers of Russian, the subjects of this research. Concerning Russophone immigrants living in Portugal, Head \& Semenova-Head (2010), based on their experience on teaching Portuguese as a Foreign Language, published a review on the main pronunciation difficulties faced by adult native Russian speakers in producing European Portuguese vowels. Among the troublesome pronunciations, they mention difficulties in distinguishing the open and close mid vowels. Russophones produced them all as mid close vowels.

\subsection{Perceptual assimilation and the Speech Learning Model}

In the linguistic literature, first explanations of the difficulties in distinguishing and producing pairs of sounds in L2, exemplified in section 2.3, have been suggested 90 years ago: Polivanov (1931) introduced the conception of phonological deafness, and Trubetzkoy (1939) the interference from phonological grids. Results from the experimental research on learning of L2 sounds have eventually evolved to the formulation of theoretical models, among those, the Speech Learning Model (SLM), developed by Flege (1995), and the Perceptual Assimilation Model (PAM), by Best (1995). Both of them are of interest to the discussion of the L2 contrasts which do not have counterparts in L1: they consider the relevance of phonetic similarities involved in processes of assimilation of two distinct sounds in L2 into one sound in L1. However, the PAM Model is based on the investigation of bilingual learners' speech productions while the SLM on those of bilingual immigrants, the aspect which is advantageous from the point of view of the research subjects' profiles considered in the present work.

The SLM introduces, among other postulates and hypotheses, the claim that the categories making up the L1 and L2 subsystems of a bilingual exist in a common phonological space in the speaker`s mind and mutually influence one another. L2 sounds are perceived as L1 sounds until new phonetic categories for these L2 sounds are established; the establishing of a new category can be blocked by equivalence classification when the L2 sound is perceived as phonetically similar to a neighboring L1 sound. The perceived phonetic dissimilarity between L2 and L1 sounds avoids the assimilation of distinct phonemic categories in L2 to only one phonemic category in L1. In addition, Flege emphasizes that new phonetic categories for L2 sounds could be established independently of the age of arrival of immigrants (Flege, 1995, 2007; Flege \& MacKay, 2011).

The concept of assimilation developed by Flege is worth considering here: the Brazilian Portuguese mid vowel system opposes open/close sounds which do not contrast phonemically in Russian. The results of the perception test, which we have developed and applied to Russophone immigrants in 
Brazil, are expected to bring evidence in relation to the formation or not of new phonetic categories for Brazilian Portuguese mid vowels by native Russian speakers.

\section{Material and Method}

\subsection{Participants}

Most of the participants were recruited through social networks (Facebook and WhatsApp groups) and were asked to perform a 10-minute perception test in the internet. The control group was composed by eight native Brazilian speakers, four from São Paulo, one from Niteroi, one from Pindamonhangaba, one from Rio de Janeiro, and one from São José dos Campos.

The first experimental group included 103 Russophones: 92 declared to be Russians, eight Ukrainians, one Belarusian and two gave incomplete information. The data about the current cities of their residence are presented on Table 3.

Table 3: The current cities of residence of the Russophone participants of the study.

\begin{tabular}{|c|c|c|}
\hline City of residence & $\begin{array}{l}\text { Number of } \\
\text { participants }\end{array}$ & Details \\
\hline São Paulo city & 41 & - \\
\hline São Paulo state & 15 & $\begin{array}{c}\text { Cities with } 2 \text { participants each one: } \\
\text { Campinas; São Bernardo do Campo; São José dos } \\
\text { Campos; Valinhos } \\
\text { Cities with 1 participant each one: } \\
\text { Atibaia; Barueri; Carapicuíba; Piracicaba; São } \\
\text { Caetano do Sul; Tanabi; Taubaté }\end{array}$ \\
\hline Rio de Janeiro city and state & 19 & $\begin{array}{c}\text { Rio de Janeiro city: } 15 ; \\
\text { Niterói: } 2 ; \text { Nova Friburgo: 1; Petrópolis: } 1\end{array}$ \\
\hline Other states of Brazil & 11 & $\begin{array}{c}\text { Cities with 2 participants each one: } \\
\text { Brasilia - DF, Florianópolis - SC } \\
\text { Cities with 1 participant each one: } \\
\text { Curitiba - PR, Fortaleza - CE, Ipatinga - MG, Porto } \\
\text { Velho - RO, Salvador - BA, Santa Maria - RS, São } \\
\text { João Del Rei - MG }\end{array}$ \\
\hline Russia* & 12 & $\begin{array}{c}\text { Moscow: 8; Saint Petersburg }-3 \\
\text { Nizhny Novgorod }-1\end{array}$ \\
\hline Other countries* & 4 & $\begin{array}{c}\text { USA: } \\
\text { Canton - 1; Chicago - 1; Philadelphia }-1 \\
\text { Germany: } \\
\text { Hamburg - } 1\end{array}$ \\
\hline No information & 1 & \\
\hline Total & 103 & \\
\hline
\end{tabular}


The study is a part of the project approved by the Ethics Committee of Pontifícia Universidade Católica de São Paulo (CAAE 09079219.9.0000.5482).

\subsection{Stimuli}

All the audio stimuli in the perception test were recorded by a female native speaker of Brazilian Portuguese, a skilled phonetician, in a sound-isolated booth. The words were pronounced in neutral speech rate and neutral pitch mean, range and variability by the Voice Profile Analysis Protocol (VPA) developed by Laver and Mackenzie-Beck (2007). The test contained three tasks: (1) an identification of an image corresponding to the audio stimulus; (2) a vowel identification; (3) a discrimination test ("odd one out") in 3-word sequences.

Task 1 included eight pairs of images. For each pair, the listeners were asked to select one image corresponding to the audio stimulus presented to them. The words illustrated by the images are listed on Table 4.

Table 4: Task 1 of the vowel perception test. List of words illustrated by the images used for the task of identification of an image corresponding to the audio stimulus.

\begin{tabular}{c|c|c|c|c|c|c}
\hline \multirow{2}{*}{$\begin{array}{c}\text { Trial } \\
\text { number }\end{array}$} & \multicolumn{3}{|c|}{ Word 1 (image at the left part of the slide) } & \multicolumn{3}{c}{ Word 2 (image at the right part of the slide) } \\
\cline { 2 - 7 } & Portuguese & Vowel & $\begin{array}{c}\text { Translation to } \\
\text { English }\end{array}$ & Portuguese & Vowel & $\begin{array}{c}\text { Translation to } \\
\text { English }\end{array}$ \\
\hline 1.1 & avó & $/ \mathrm{o} /$ & grandmother & $a v \hat{o}$ & $\mathrm{/} /$ & grandfather \\
\hline 1.2 & chopp & $/ \mathrm{o} /$ & draught beer & shop & $/ \mathrm{J} /$ & shop \\
\hline 1.3 & sede & $/ \varepsilon /$ & head office & sede & $/ \mathrm{e} /$ & thirst \\
\hline 1.4 & mel & $/ \varepsilon /$ & honey & meu & $/ \mathrm{e} /$ & my \\
\hline 1.5 & poço & $/ \mathrm{o} /$ & (a) well & posso & $/ \mathrm{J} /$ & (I) can \\
\hline 1.6 & apé & $/ \varepsilon /$ & by foot & apê & $/ \mathrm{e} /$ & $\begin{array}{c}\text { a short form of } \\
\text { the "apartment" }\end{array}$ \\
\hline 1.7 & corte & $/ \mathrm{o} /$ & haircut & corte & $/ \mathrm{o} /$ & court \\
\hline 1.8 & molho & $/ \mathrm{o} /$ & sauce & molho & $/ \mathrm{J} /$ & $\begin{array}{c}\text { (I) wet } \\
\text { (something) }\end{array}$ \\
\hline
\end{tabular}

The figures were taken from sources openly available on the Internet. The listener had only two options: to select the left image or the right image.

Task 2 consisted of a vowel identification in four audio stimuli. Each audio stimulus was followed by audio recordings of three vowels (Table 5). The listener could select one of the vowels or the "I don't know" button. 
Table 5: Task 2 of the vowel perception test. List of audio stimuli used for the vowel identification.

\begin{tabular}{c|c|c|c|c|c|c}
\hline $\begin{array}{c}\text { Trial } \\
\text { number }\end{array}$ & $\begin{array}{c}\text { Portuguese } \\
\text { word }\end{array}$ & Vowel & \multirow{2}{*}{$\begin{array}{c}\text { Translation } \\
\text { to English }\end{array}$} & \multicolumn{3}{|c}{$\begin{array}{c}\text { Audio recordings of vowels to } \\
\text { select }\end{array}$} \\
\cline { 5 - 7 } & & & & 1 & 2 & 3 \\
\hline 2.1 & pelo & $/ \mathrm{e} /$ & hair & $/ \varepsilon /$ & $/ \mathrm{e} /$ & $/ \mathrm{a} /$ \\
\hline 2.2 & posso & $/ \mathrm{\rho} /$ & (I) can & $/ \mathrm{\rho} /$ & $/ \mathrm{o} /$ & $/ \mathrm{a} /$ \\
\hline 2.3 & sede & $/ \varepsilon /$ & head office & $/ \varepsilon /$ & $/ \mathrm{e} /$ & $/ \mathrm{a} /$ \\
\hline 2.4 & shop & $/ \mathrm{\rho} /$ & shop & $/ \mathrm{\rho} /$ & $/ \mathrm{o} /$ & $/ \mathrm{a} /$ \\
\hline
\end{tabular}

Task 3 consisted of a discrimination test ("odd one out"): the listeners were required to point out the non-repeated word in 3-word sequences. It contained 18 minimal pairs. First, the listener had to say if the same word was repeated or whether the words were different. Second, if the words seemed to be different, the listener was asked to select the different one: Word 1, Word 2, or Word 3 (Table 6).

Table 6: Task 3 of the vowel perception test. List of audio stimuli used for the discrimination test.

\begin{tabular}{|c|c|c|c|c|c|}
\hline Trial number & Word 1 & Word 2 & Word 3 & Different word & In English \\
\hline 3.1 & t/o/rre & t/o/rre & t/o/rre & No & tower \\
\hline 3.2 & $\mathrm{p} / \mathrm{s} / \mathrm{sso}$ & $p / \mathrm{p} / \mathrm{sso}$ & $\mathrm{p} / \mathrm{o} / \mathrm{ço}$ & 3 & (I) can / (a) well \\
\hline 3.3 & $p / \varepsilon / s o$ & $p / e / s o$ & $p / e / s o$ & 1 & (I) weight / (a) weight \\
\hline 3.4 & $\operatorname{colh} / \varepsilon / r$ & colh/e/r & $\operatorname{colh} / e / r$ & 1 & spoon / (to) pick \\
\hline 3.5 & colh/e/r & colh/e/r & colh/e/r & No & (to) pick \\
\hline 3.6 & $\mathrm{~g} / \mathrm{e} / \mathrm{lo}$ & $\mathrm{g} / \mathrm{e} / \mathrm{lo}$ & $\mathrm{g} / \varepsilon / l o$ & 3 & (an) ice / (I) chill \\
\hline 3.7 & $\mathrm{p} / \mathrm{s} / \mathrm{sso}$ & $p / o / c ̧ o$ & $\mathrm{p} / \mathrm{s} / \mathrm{sso}$ & 2 & (I) can / (a) well \\
\hline 3.8 & t/o/rre & t/o/rre & t/o/rre & 2 & tower / toast (imp.) \\
\hline 3.9 & $p / \varepsilon / s o$ & p/e/so & $p / \varepsilon / s o$ & 2 & (I) weight / (a) weight \\
\hline 3.10 & t/o/rre & t/s/rre & t/s/rre & 1 & tower / toast (imp.) \\
\hline 3.11 & $p / \varepsilon / s o$ & $p / \varepsilon / s o$ & $p / \varepsilon / s o$ & No & (I) weight \\
\hline 3.12 & av/o/ & av/o/ & av/o/ & No & grandfather \\
\hline 3.13 & colh/e/r & $\operatorname{colh} / \varepsilon / r$ & $\operatorname{colh} / \varepsilon / r$ & 1 & (to) pick / spoon \\
\hline 3.14 & p/o/ço & $\mathrm{p} / \mathrm{o} / \mathrm{c} o$ & $\mathrm{p} / \mathrm{o} / \mathrm{c} \mathrm{o}$ & No & (a) well \\
\hline 3.15 & $\mathrm{~g} / \mathrm{e} / \mathrm{lo}$ & $\mathrm{g} / \varepsilon / l o$ & $\mathrm{~g} / \mathrm{e} / \mathrm{lo}$ & 2 & (an) ice / (I) chill \\
\hline 3.16 & av/o/ & av/ol & av/o/ & No & grandmother \\
\hline 3.17 & $\mathrm{~g} / \varepsilon / l o$ & $\mathrm{~g} / \varepsilon / l o$ & $\mathrm{~g} / \mathrm{e} / \mathrm{lo}$ & 3 & (I) chill / (an) ice \\
\hline 3.18 & av/o/ & av/o/ & av/o/ & 3 & $\begin{array}{l}\text { grandmother / } \\
\text { grandfather }\end{array}$ \\
\hline
\end{tabular}

All stimuli were embedded in videos. The videos from Task 1 had as a background the respective pairs of images. The audio stimuli from Tasks 2 and 3 were embedded in videos with the same blue background. The 30 trials containing the videos were incorporated in a Google form available at link 
https://docs.google.com/forms/d/16C3Ektdfj3cPIIkQnnTK6FIsWrnUY6Jd3YOs1wZfdyI/edit?usp=sharin g.

\subsection{Procedures}

The participants performed the perception test online in a place convenient to them. They were informed that the test took 8-10 minutes, required listening to short audio recordings, and were asked to use headphones. In addition, they were asked to answer questions about their nationality, the current place of residence, time of residence in Brazil, and the way they learned Brazilian Portuguese. There was also a place for optional free-response comments. Upon completing the test, the participants automatically received a link to their results containing the answers and could listen the tasks again for their information. They also could write additional comments in the social network (groups of Russophones living in Brazil on Facebook and the timeline of one of the authors of this article) where the test was posted. All the data were collected between February 2019 and March 2020.

\subsection{Statistical analysis}

The mean and median percentages of correct answers and their standard deviations $(S D)$ were calculated for each group. For other statistical analysis, several online tools were used. The characteristics of normal distribution were verified through the Kolmogorov-Smirnov (K-S) test of normality (Stangroom, 2020). When the K-S test statistic $(D)$ is low and the p-value is $>0.05$, it means that the data do not differ significantly from those which are normally distributed.

The correlation for the data that do not follow the normal distribution was verified through Spearman's Rho Calculator (Stangroom, 2020). Comparisons between two samples containing the normally distributed, non-paired data were performed through the non-paired t-test (Stangroom, 2020). Multiple groups with normal distribution were compared using ANOVA (Stangroom, 2020), F-stat and $p$ value were verified.

\section{Results}

\subsection{Validation of the Brazilian Portuguese vowel perception test on Brazilians}

The perception test of the Brazilian Portuguese open and close mid vowels was validated with eight native Brazilians. The mean percentage of the correct answers was 99\% ( $S D=1.9 \%)$. Six control participants were at ceiling $(100 \%)$, one made one mistake, and another two mistakes.

\subsection{The Brazilian Portuguese vowel perception by the native Russian speakers}

We obtained results of the perception test of the Brazilian Portuguese open and close mid vowels from 103 native Russian speakers. The percentage of correct answers for each trial is shown on Table 7. The mean percentage of the correct answers for Task 1 (Image identification) was 70\% ( $S D=16 \%$ ); for Task 2 (Vowel identification), it was 71\% ( $S D=14 \%$ ); and for Task 3 (Word discrimination), it was 67\% (SD $=16 \%)$. As the means were very similar, we aggregated the data for future analyses. The data are normally distributed (the K-S test statistic $(D)=0.11293$, $p$-value $=0.79836$ ).

Considering the vowels pairs in 30 trials of the test, 16 trials tested the perception of the contrast $/ \mathrm{s} / \mathrm{/} / \mathrm{o} /$ and $14 / \varepsilon /-/ \mathrm{e} /$. For the pair $/ \mathrm{s} /-/ \mathrm{o} /$, the mean percentage of the correct answers was $67 \%(S D=$ 
$15 \%)$; for $/ \varepsilon /-/ e /$, it was $71 \%(S D=16 \%)$. As both distributions are normal and $S D s$ similar, we used non-paired t-test to compare the percentages of right answers between both vowel pairs: there was no difference $(t$-value $=-0.66806$, the $p$-value $=0.509568)$. Three most difficult trials with the percentage of correct answers less than 50\% were 3.4 (Table 6), 1.2 (Table 4) and 3.15 (Table 6).

Table 7: Percentage of correct answers for each trial of the perception test of the Brazilian Portuguese open and close vowels, performed by 103 native Russian speakers. The tasks description could be found in Tables 4, 5 and 6 through the trial identification number.

\begin{tabular}{|c|c|c|c|c|c|}
\hline $\begin{array}{c}\text { Trial } \\
\text { identification } \\
\text { number }\end{array}$ & $\begin{array}{l}\text { Percentage of } \\
\text { correct answers } \\
\text { for the trial }(\%)\end{array}$ & Pair of vowels & $\begin{array}{c}\text { Trial } \\
\text { identification } \\
\text { number }\end{array}$ & $\begin{array}{l}\text { Percentage of } \\
\text { correct answers } \\
\text { for the trial }(\%)\end{array}$ & Pair of vowels \\
\hline 1.1 & 66 & $/ \mathrm{s} /-/ \mathrm{o} /$ & 3.4 & 38 & $\mid \varepsilon /-/ \mathrm{e} /$ \\
\hline 1.2 & 43 & $/ \mathrm{J} / \mathrm{-} / \mathrm{O} /$ & 3.5 & 64 & $\mid \varepsilon /-/ \mathrm{e} /$ \\
\hline 1.3 & 72 & $/ \varepsilon /-/ \mathrm{e} /$ & 3.6 & 96 & $/ \varepsilon /-/ \mathrm{e} /$ \\
\hline 1.4 & 85 & $\mid \varepsilon /-/ \mathrm{e} /$ & 3.7 & 66 & $/ \mathrm{s} / \mathrm{-} / \mathrm{o} /$ \\
\hline 1.5 & 56 & $/ \mathrm{J} /-/ \mathrm{O} /$ & 3.8 & 69 & $/ \mathrm{o} / \mathrm{-} / \mathrm{o} /$ \\
\hline 1.6 & 83 & $/ \varepsilon /-/ \mathrm{e} /$ & 3.9 & 54 & $\mid \varepsilon /-/ \mathrm{e} /$ \\
\hline 1.7 & 62 & $/ \mathrm{s} /-/ \mathrm{O} /$ & 3.10 & 88 & $/ \mathrm{d} / \mathrm{-} / \mathrm{o} /$ \\
\hline 1.8 & 91 & $/ \mathrm{J} /-/ \mathrm{o} /$ & 3.11 & 83 & $/ \varepsilon /-/ \mathrm{e} /$ \\
\hline 2.1 & 77 & $/ \varepsilon /-/ \mathrm{e} /$ & 3.12 & 87 & $/ \mathrm{d} / \mathrm{-} / \mathrm{o} /$ \\
\hline 2.2 & 50 & $/ \mathrm{J} /-/ \mathrm{o} /$ & 3.13 & 60 & $\mid \varepsilon /-/ \mathrm{e} /$ \\
\hline 2.3 & 81 & $/ \varepsilon /-/ \mathrm{e} /$ & 3.14 & 58 & $/ \mathrm{s} / \mathrm{-} / \mathrm{o} /$ \\
\hline 2.4 & 75 & $/ \mathrm{J} /-/ \mathrm{o} /$ & 3.15 & 46 & $/ \varepsilon /-/ \mathrm{e} /$ \\
\hline 3.1 & 78 & $/ \mathrm{J} /-/ \mathrm{o} /$ & 3.16 & 50 & $/ \mathrm{s} / \mathrm{-} / \mathrm{o} /$ \\
\hline 3.2 & 77 & $/ \mathrm{J} /-/ \mathrm{o} /$ & 3.17 & 78 & $/ \varepsilon /-/ \mathrm{e} /$ \\
\hline 3.3 & 70 & $/ \varepsilon /-/ \mathrm{e} /$ & 3.18 & 51 & $/ \mathrm{d} / \mathrm{-} / \mathrm{o} /$ \\
\hline
\end{tabular}

The mean percentage of the correct answers was $68 \%(S D=14 \%)$. The median was $70 \%$. The percentage of the correct answers varied from 20 to $100 \%$. Only $14 \%$ obtained more than $80 \%$ right answers; only four participants out of 103 obtained more than $90 \%$ correct answers, three of them being 100\% successful (Figure 5).

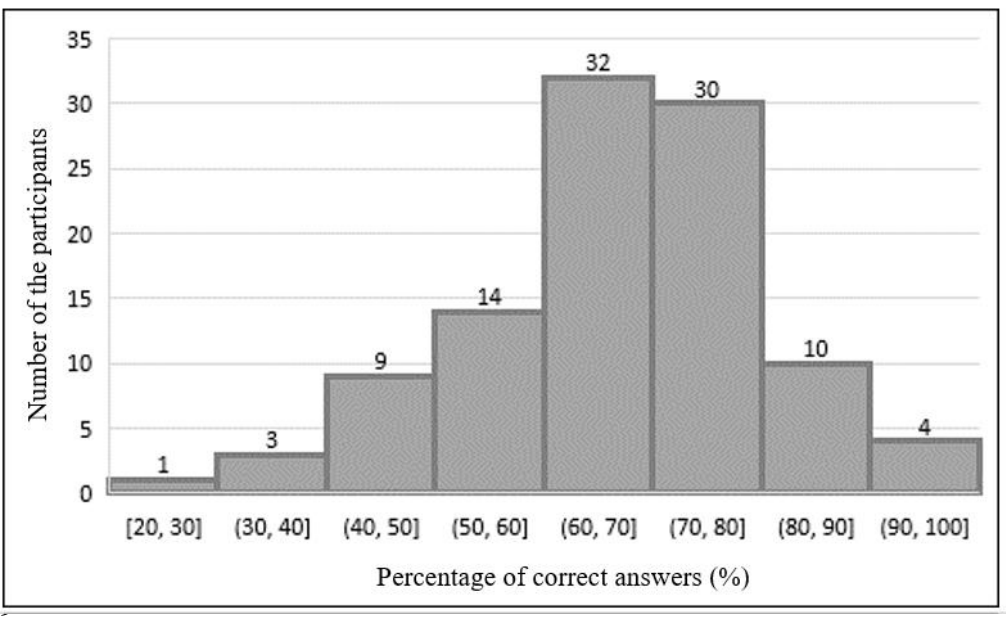


Figure 5: Number of the participants according to the percentage of the correct answers obtained in the perception test of the Brazilian Portuguese open and close mid vowels performed by 103 native Russian speakers.

As the Russian test participants lived in different places in Brazil and 16 lived abroad, we have also analyzed the percentage of the correct answers obtained strictly from 41 native Russian speakers living in São Paulo city. In this case, the mean value was $70 \%(S D=10 \%)$. The distributions of the correct answers in the group of participants living in São Paulo and all the others were not different ( $t$-value $=$ 0.90661 , the $p$-value $=0.183385$ ), so, for further analysis, we have used the date from the aggregated group.

\subsection{Results in relation to the way of learning Brazilian Portuguese by native Russian speakers}

We have also analyzed the percentage of correct answers in the group of native Russian speakers in relation to their way of learning Brazilian Portuguese (Table 8). Only one participant did not provide this information. The way the Russophones had learned Brazilian Portuguese had no effect on the percent of correct answers: the mean values of the correct answers in all the groups were similar (ANOVA: F-Stat $=$ $0.3305, p=0.8934)$.

Table 8: Percentage of correct answers in the perception test of the Brazilian Portuguese open and close vowels performed by 103 native Russian speakers organized accordingly to the kind of instruction in Brazilian Portuguese.

\begin{tabular}{c|c|c}
\hline $\begin{array}{c}\text { Kind of instruction in Brazilian } \\
\text { Portuguese }\end{array}$ & Number of participants & $\begin{array}{c}\text { Percentage of correct answers, } \\
\text { mean } \pm S D, \%\end{array}$ \\
\hline Language school in Brazil & 7 & $72 \pm 17$ \\
Alone after moving to Brazil & 57 & $68 \pm 13$ \\
With Brazilian private teachers & 11 & $65 \pm 8$ \\
With non-Brazilian private teachers & 6 & $67 \pm 16$ \\
A language school in home country & 9 & $69 \pm 12$ \\
Alone while in home country & 12 & $71 \pm 20$ \\
No response & 1 & $68 \pm 14$ \\
\hline Total & 103 &
\end{tabular}

\subsection{Results in relation to the time of residence in Brazil}

Only five out of 103 native Russian participants did not provide information about their time of residence in Brazil. Six participants had never been in Brazil but learned Brazilian Portuguese in Russia, on their own (four) or in a language school (two). Within the group of 92 participants that provided information on time residence and had lived in Brazil, the mean residence time in Brazil was 6.7 years $(S D=4.4$ years), the median was 5 years (range: 3 months - 2 years). The distribution of the residence time was not normal (the K-S test statistic $(D)=0.15844, p$-value $=0.0129$ ) (Figure 6). There was no correlation between the number of correct answers and the time of residence in Brazil (Spearman's Rho = $0.07184, \mathrm{p}=0.4821$ ). 


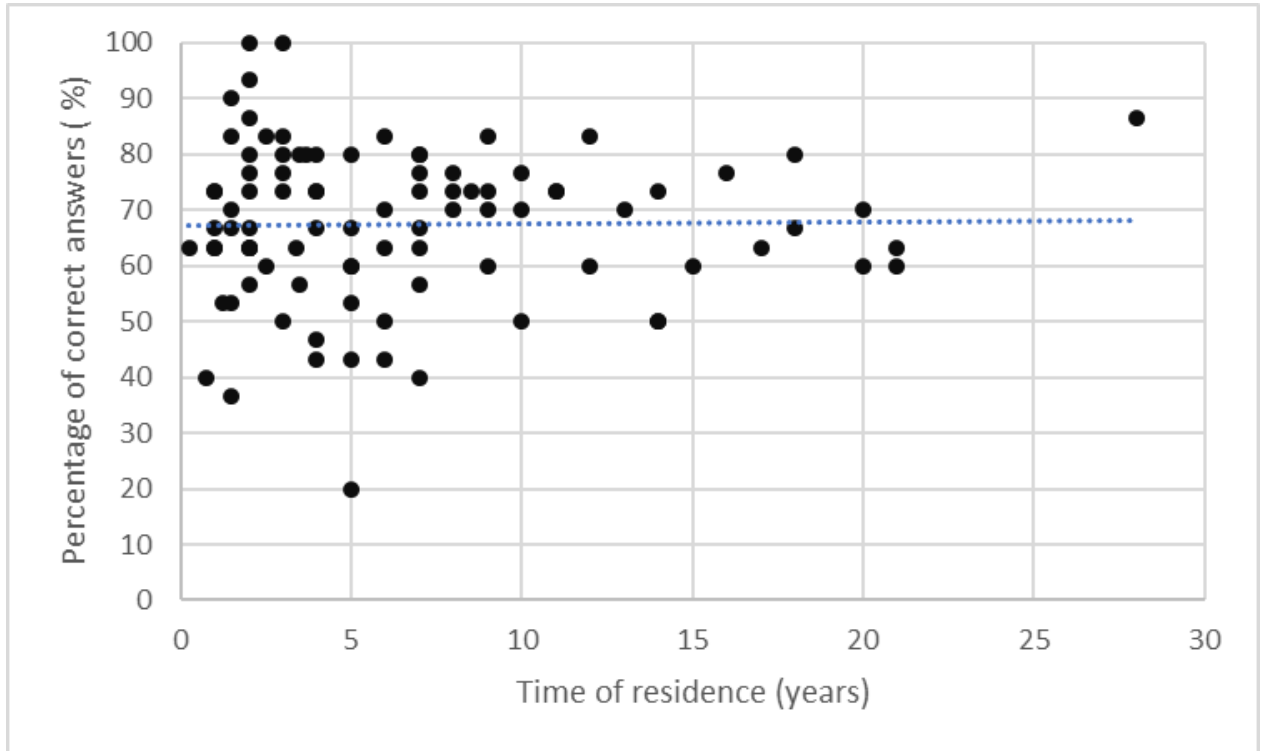

Figure 6: Percentage of correct answers in identification of the open/close mid vowels, and time of residence of Russophone immigrants in Brazil. The figure present data obtained from 92 participants. The blue line is a trend line.

\subsection{Monitoring of the feedback from Russophones in relation to the Brazilian Portuguese vowel perception test}

The goal of this test was to investigate one of the main difficulties of Russophones regarding the phonetics of Brazilian Portuguese, so we expected that it would provoke emotional comments and questions. For that reason, we have monitored their comments.

We first analyzed the optional free-responses comments written by participants at the end of the test. All the Russophones wrote in Portuguese. The comments were classified as: (1) technical details (three participants); (2) grateful (four just "thank you"); (3) questions (two questions: one person asked about the results of native Brazilians; another asked if the voice on the recordings belonged to a foreigner), (4) wishes (one participant wrote "I would like to have a phone application of this type for the perception training"), (5) comments about the difficulty of the test (three participants saying "Very difficult" or "Not easy") and (6) emotional comments (four participants). The emotional comments were "It killed me!" (a participant with 57\% of correct answers), "It was frustrating. All seemed to be equal" (a participant with $80 \%$ of correct answers), "Oh my brain!" (a participant with $80 \%$ of correct answers) and one person wrote, "some words are pronounced in the manner to induce to errors" (a participant with $67 \%$ of correct answers). These comments were considered expressions of emotion.

Secondly, we analyzed comments in three Russophone social network groups on Facebook where the test was advertised and on the timeline of our researcher who invited Russophones friends living in Brazil for participating in the test. These comments were written in Russian, and the researcher answered most of them to encourage communication. We counted 31 relevant interactions (some persons commented in more than one group), which produced 72 relevant comments (not considering the researcher`s answers). We present hereafter some comments obtained from 18 participants, translated and slightly summarized:

(1) "It was very interesting. I had seven errors. It was especially difficult when the intonation changed, this made us think that the vowel was different. But when you get the right answers 
after finishing the test you manage to perceive the difference between the two sounds, even if it did not work at the first time. Even the solfege sometimes is simpler."

(2) "Nine errors. I nearly felt crazy. Mainly in the third part."

(3) "I will ask my (Brazilian) husband to do the test."

(4) "I'm not able to perceive 50 shades of Brazilian "o", my ears do not function, I could understand when observing the lips, but not hearing. The vowels in Portuguese are really troublesome, they are absolutely the same. Even worse, before this test, I had trained to pronounce sounds with some Brazilians and Portuguese audio recordings. In real life, we do not have difficulties to differentiate avô and avó, Brazilians always say meu avô or minha avó. But these crazy people differentiate the words in some way..."

(5) "When I arrived in Brazil, I did not know about the different sounds, I memorized the words in the manner I was hearing them, all the "o" and "e" were the same. Now, if I hear just sounds, in good conditions, not absolutely sure, but I can perceive the differences; but within a word, Im not able to do that because I do not know which vowel is supposed to be there. For me, the first part of the test was the most difficult. We should learn all the words again. When you hear something, you should know what to pay attention to, only then it will work."

(6) "For me, these "o" and "e" was a discovery at the moment when I already had been studying Portuguese for two years and was quite fluent. The problem was not just phonetics, but to understand who is who. In the context, I could understand. But in the test, I was not able to identify the words."

(7) "Six errors. In everyday life, it is very difficult to hear the difference! My Brazilian husband had no errors. He was $100 \%$ right and had no doubts."

(8) "I had 13-14 errors. In some questions, I answered correctly that the words were not equal, but I chose the wrong word. Some words I did not know. But for me it is not a big deal. I do not have problems in everyday communication. We always can understand the word by the context, "a cut" or "a court"."

(9) "I know that I could not perceive the difference. But I will do the test again just to be sure."

(10) "Me too, I'm sure that I do not recognize them, it is not my first time."

(11) "I just add minha or meu before the word, so the context makes clear if it is avó or avô."

(12) "Really, it is not a very nice test. I felt like an idiot. After 18 years of living in the country, I'm not able to perceive the differences so clear for Brazilians. My result was not so bad, six errors in 30 questions. But I felt very angry, not identifying some sound differences. I felt impotent hearing some audios."

(13) "Corte and molho could be two different words each one?! How?!".

(14) "I only discovered the difference answering the test. I questioned my husband, how it could be possible that one written word could be pronounced in different manners? He was surprised and told me, one is a verb, another is a noun. It is obvious, right?"

(15) "Could you confirm that Brazilians do the test 100\% correctly?"

(16) "I was surprised with apé and apê. I should learn a lot!"

(17) "Only three errors. I came when I was 15 years old. Since I had a good base of French, I learned Portuguese during my first year in the country... I mean the vocabulary; the pronunciation took many years. An interesting detail is that, even after so many years, I was able to perceive the difference between the vowels, but I had pronunciation errors. It is just 


\section{Smirnova Henriques, Skrelin, Evdokimova, Kachkovskaia, Borrego, Piccolotto Ferreira, Piccin Bertelli Zuleta, Ruseishvili and Madureira}

physiological. I can't pronounce some sounds. Sometimes I tell something and only seeing my husband's smile I understand that it did not work."

(18) "It is funny that I nearly always hear something different, but I select the wrong word."

The above-mentioned comments are illustrative of the kinds of issues faced by immigrants in Brazil. Many of them are aware of their difficulties in discriminating Brazilian Portuguese speech sounds, but they are not able to improve their perceptual or production performance without the help of formal training in phonetics. This kind of training is thought to be beneficial for L2 learners in general.

\section{Discussion}

In the current work, we have developed an online test for the evaluation of the perception of the Brazilian Portuguese open and close mid vowels $/ \varepsilon /-/ \mathrm{e} /$ and $/ \mathrm{\rho} / \mathrm{-} / \mathrm{\rho} /$ and administered it to 103 native speakers of Russian. Eighty-four out of 103 Russophones were residing in Brazil at the time of the experiment. Most of the others had already lived in Brazil and had gone away. Only six Russophones did not have such experience and they were included in the analysis to verify if the time of residence in Brazil influenced the perception ability to differentiate the Brazilian Portuguese mid vowels.

The perception test included 30 trials distributed in three types of tasks: image identification, vowel identification, and word discrimination (Tables 4, 5, 6). The analyses of the results confirmed our main hypothesis: the difficulty of the native Russian speakers to differentiate the Brazilian Portuguese mid vowels, communicated to us through the previously applied questionnaires and interviews (Smirnova Henriques et al., in press), is real and quantifiable. The mean percentage of the correct answers in the Russophone group was $68 \%$ (Table 8), while in the Brazilian control group 99\%. The scores obtained by the Russophones are quite similar to the results of the perception tests obtained on L2 learners of Brazilian Portuguese with L1 Spanish or L1 English (Allegro, 2010; Feiden et al., 2014; Kendall, 2004; Simões \& Kelm, 1991).

Our second hypothesis was that the Russophones' perceptual ability in discriminating the openclose mid vowel contrasts was affected by kind of language instruction received and their time of residence in Brazil. In answering the questionnaire, 56\% of the Russophones participants reported that they learned the Portuguese language on their own after moving to Brazil (Table 8). Only 18\% of the participants learned Portuguese after their arrival in Brazil, either having private tutoring or studying in language schools. All the participants volunteered to take part in our vowel perception test by following a link in social networks. Therefore, we have all the reasons to believe that they were interested in learning. This confirms that troublesome situation involving access to learning Brazilian Portuguese as a Foreign Language, both in Brazil and in Russia (Adam et al., 2009; Arefiev, 2019; Amado, 2013; Lopez, 2016; Farneda, 2019; Miranda \& Lopez, 2019).

When we examined the relationship between the perception of Brazilian Portuguese vowels by Russophones and the type of language instruction they received, the groups of Brazilian Portuguese learners who studied the language with a Brazilian teacher or in a Brazilian language school did not show a higher perception ability for the mid vowel differentiation (Table 8). This means that Brazilian language instructors are probably not focusing on phonetics training: in fact, the teachers of Portuguese as a Native Language are not taught how to train non-native speakers, and opportunities for the professionalization in teaching Portuguese as a Foreign Language are very few (Farneda, 2019). Our results draw attention to 
the importance of expanding the opportunities for learning Brazilian Portuguese as a Foreign Language in Brazil and abroad and the urgent need for the preparation of adequate phonetics materials for non-native speakers.

Considering the time of residence in Brazil, we verified that there was no correlation between the time of residence and the percentage of the correct answers given by the Russophones (Table 9). Our results support Flege's hypothesis that the capacity of creating a new phonetic category does not depend directly on the time of residence, but on the quality and quantity of input (Flege, 1995, 2007; Flege \& MacKay, 2011). To quantify the input is not an easy task and includes much information about family, friends, kind of language instruction received, jobs hobbies, and many other personal details, not possible to be included in a short questionnaire. However, this could be done in further experiments with Russophones whose sociolinguistic profiles are characterized in detail in our database (Smirnova Henriques et al., in press).

The Russian vowel system does not have mid vowel contrasts, and their realization depends on the palatalization of the preceding consonant (Ordin, 2011). This allophonic variation in Russian does not help to develop an improved perception of the phonemic contrast of the mid vowels in Brazilian Portuguese. The reason is that Russophones never need to discriminate words based on the mid openclose vowel contrasts in their native language and this makes them assimilate the two Brazilian Portuguese mid front vowels into Russian /e/ and the two Brazilian Portuguese mid back vowels into Russian /o/. In addition, the perception of homograph words in a real speech in Brazilian Portuguese could be based on the linguistic context, and this does not favor the sound perception ability: in these conditions, listeners do not need to draw attention to the vowel quality (Kendall, 2004).

The monitoring of the feedback to our perception test in social networks shows that most of the participants were aware of having problems with the discrimination of the Brazilian Portuguese mid vowel contrasts and were frustrated by that. At the same time, four out of 18 participants who wrote relevant comments questioned if the Brazilians are able to discriminate or asked their Brazilian family members to take the test. Following our personal observations and the information obtained from previous interviews (Smirnova Henriques et al., in press), this is a common reaction when a Russophone is told about the Brazilian Portuguese mid vowel open/closed contrast the first time. However, even the Russophones who are aware of the phonemic contrast in some very frequent word pairs as avólavô became surprised by the existence of homographs in pairs a verb/a noun, as gelo and soco as showed in Figure 2. Three Russophones wrote comments in an online discussion with one researcher of our group, surprised by such homograph examples: they were living in Brazil for 21, 7 and 6 years at the moment of the test, respectively, one university professor and two language instructors. Only two participants out of the 18 wrote that they do not worry about these vowels because it was not critical for their everyday life communication and they could understand the words within context. Eventually, this feeling depends on the situation faced by the nonnative speaker and can change over time.

Online testing has some shortcomings: the sample could be biased to the younger people and the data only could be collected from the participants who have access to the Internet. However, in our case we were interested just in recently arrived immigrants and not in old immigration wave which represents early bilinguals who arrived in Brazil in the 1950s (Ruseishvili, 2016). Most Russophone migrants are not elderly adults who has arrived in Brazil mainly during the last 12 years (Smirnova Henriques et al., in press): in 2008 the visa policy changed and Russians got the opportunity to enter Brazil without a tourist visa and discover the country. In addition, they nearly always have access to the Internet because they keep relationships with their family and friends abroad and belong to the social class which is able to pay 
an expensive ticket from Europe to Brazil. In these conditions, the online format brings new participants and does not impose limitations.

As next steps, we intend to investigate whether Russophones can distinguish the Brazilian Portuguese open and close mid vowel contrasts in speech production, and which sociolinguistic factors could affect the perception and production of these vowels The most important factors are known to be the quality and quantity of input (Flege, 1995, 2007); however, they are difficult to be quantified, especially in the situation of the lack of any formal instruction when length of learning could not be defined. Following the data of the current study, very frequently the first contact of Russophones with Brazilian Portuguese begins upon arrival to Brazil; however, the length of residence in our experiments was not shown to be important for improving the mid vowel perception. We plan further study in more details the profiles of 24 participants of the current study who filled a very detailed questionnaire containing questions on the following items: (1) personal data; (2) migrant trajectory; (3) current contact with the Russian language; (4) self-evaluation of the proficiency level in Portuguese and exposure to the Portuguese language; (5) general linguistic evaluation; (6) phonetic difficulties (Smirnova Henriques et al., in press). All this information might help to elucidate the factors that influence the ability to differentiate the Brazilian Portuguese mid vowels and provide a framework for the consideration of the quality and quantity of input (Flege, 1995, 2007; Flege \& MacKay, 2011). Our recent pilot study showed that the perception of speakers' characteristics by Brazilians is influenced by the degree of the Russian accent in the speech, so this study would be important both for the field of experimental phonetics and sociolinguistics (Smirnova Henriques \& Madureira, 2019). We also intend to create a training corpus and develop strategies for perception training of the Brazilian Portuguese mid vowels monitoring their efficiency at different time points.

\section{Conclusion}

The results of our perceptual experiment provided further evidence for the following claims by Flege (1995): L2 sound assimilation into L1 sounds, merging of two sounds in one category, establishment of perceptual equivalence categorization and blocking of new categories in L2. As a shortcoming, the fact that the participants of our experiment were adults, we were not able to evaluate if the age of learning was a significant variable or not.

\section{Acknowledgments}

Dr. Smirnova Henriques is supported by postdoctoral fellowship PNPD/CAPES (Programa Nacional de Pós-Doutorado da Coordenação de Aperfeiçoamento de Pessoal de Nível Superior). We thank Dr. Irina A. Sekerina, Professor at City University of New York - College of Staten Island, for revision of the manuscript and helpful discussions. Our thanks to the anonymous reviewers for the pertinent suggestions they made. We also thank Dr. Letícia Pereyron from University of Sydney for the kindly provided figure.

\section{REFERENCES}


The perception of Brazilian Portuguese open and close mid vowels by native Russian speakers

1. Adam ARS, Fernandes Massuci C, Furtoso VB. Formação de professores de PFOL na graduação: relato de experiência. In: Furtoso VB. (Org.) Formação de professores de Português para Falantes de Outras Línguas. Londrina: Eduel, 2009. pp. 65-76.

2. Allegro FRP. Percepção das vogais do português por hispanofalantes: um estudo envolvendo paulistanos e rio-platenses. Revista Intercâmbio. São Paulo: LAEL/PUC-SP, v. 22, pp. 56-71, 2010. https://revistas.pucsp.br/intercambio/article/view/8247

3. Amado RS. O ensino de português como língua de acolhimento para refugiados. In: Revista da Sociedade Internacional Português Língua Estrangeira - SIPLE. Brasília, ed. 7, ano 4, n. 2, 2013.

4. Arefiev A. Sotrudnichestvo Rossii i Portugalii v oblasti obrazovaniya $i$ vzaimnoe izuchenie iazykov [Cooperation between Russia and Portugal in the education field and mutual learning of languages. In Russian]. In: Slavica Helsingiensia 52. Russian Language in the Multilingual World. Helsinki: University of Helsinki, 2019. pp. 123-133. https://blogs.helsinki.fi/slavica-helsingiensia/slavica-helsingiensia-52/

5. Barbosa PA "Syllable-timing in Brazilian Portuguese": uma crítica a Roy Major. DELTA, v. 16, n. 2, pp. 369-402, 2000. http://dx.doi.org/10.1590/S0102-44502000000200006

6. Barbosa PA, Albano EC. Brazilian Portuguese. Journal of the International Phonetic Association, v. 34, n. 2, pp. 227-232, 2004.

7. Barbosa PA, Madureira S. Manual de Fonética Acústica Experimental: aplicações a dados do português. São Paulo: Cortez; 2015.

8. Best CT. A direct realistic perspective on cross-language speech perception. In: Strange W (Ed.) Speech perception and linguistic experience: issues in cross-language research. Timonium, MD: York Press, 1995. pp. 171-204.

9. Bondarko LV. Foneticheskoe opisanie iazyka i fonologicheskoe opisanie rechi [Phonetical description of language and phonological description of speech]. Leningrad, Izd-vo Leningradskogo universiteta, 1981.

10. Bondarko LV, Verbitskaia LA, Zinder LR, Geilman II, Svetozarova ND, Stern AS. et al. Fonetika spontannoi rechi [Phonetics of the spontaneous speech]. Leningrad, Izd-vo Leningradskogo universiteta, 1988.

11. Bondarko LV. Foneticheskiy fond sovremennogo russkogo iazyka [The Phonetic Fund of contemporary Russian Language]. Voprosy iazykoznaniia, 3, pp. 15-19, 1989.

12. Bondarko LV. Phonetic and phonological aspects of the opposition of 'soft' and 'hard' consonants in the modern Russian language. Speech Communication, v. 47, pp. 7-14, 2005. https://doi.org/10.1016/j.specom.2005.03.012

13. Bondarko LV. Short description of Russian sound system. In: Silva V. de, Ullakonoja R. (Eds.) Phonetics of Russian and Finnish: General description of phonetic systems. Experimental studies on spontaneous and read-aloud speech. Frankfurt-am-Main: Peter Lang, 2009. pp. 23-35.

14. Brasil. Portaria Interministerial $\mathrm{n}^{\circ} 11$, de 3 de maio de 2018. Dispõe sobre os procedimentos para solicitação de naturalização, de igualdade de direitos, de perda, de reaquisição de nacionalidade brasileira e de revogação da decisão de perda da nacionalidade brasileira e dá outras providências. Diário Oficial da União: seção 1, Brasília, DF, ed. 85, p.46, 04/05/2018.

15. Câmara Jr JM. Estrutura da língua portuguesa. 40. Ed. Petrópolis, RJ: Vozes, 2007 [1970].

16. Castilho FARO. Questões de pronúncia em língua inglesa: fatores desencadeantes da percepção do sotaque do falante brasileiro de língua inglesa em relação à produção dos sons fricativos alveolares. Dissertação (Mestrado em Linguística Aplicada e Estudos de Linguagem) - PEPG de Linguística Aplicada e Estudos de Linguagem, Pontifícia Universidade Católica de São Paulo, São Paulo, 2004. https://www.pucsp.br/liaac/download/fabiola.pdf

17. Cavalcanti L, Oliveira T, Macedo M. Resumo Executivo. Relatório Anual 2018. Observatório das Migrações Internacionais; Ministério do Trabalho/ Conselho Nacional de Imigração e Coordenação Geral de Imigração. Brasília, DF: OBMigra; 2018. http://obmigra.mte.gov.br/index.php/publicacoes-obmigra 
18. Díaz Granado M. L2 and L3 Acquisition of the Portuguese Stressed Vowel Inventory by Native Speakers of English. Ph.D. Thesis - University of Arizona, Tucson, AZ, 2011. https://repository.arizona.edu/handle/10150/225892

19. Diniz de Figueiredo EH. Second language acquisition in Brazil since the social turn. Rev. bras. linguist. apl., v. 18, n. 1, 2018. DOI: 10.1590/1984-6398201812420.

20. Egorova O. Vowel Features in Spontaneous and Read-Aloud Russian. Silva V. de, Ullakonoja R. (Eds.) Phonetics of Russian and Finnish: General description of phonetic systems. Experimental studies on spontaneous and read-aloud speech. Frankfurt-am-Main: Peter Lang, 2009. pp. 89-114.

21. Elvin J, Escudero P, Vasiliev P. Spanish is better than English for discriminating Portuguese vowels: acoustic similarity versus vowel inventory size. Front Psychol, v. 5, article 1188, pp. 1-8, 2014. https://www.frontiersin.org/articles/10.3389/fpsyg.2014.01188/full

22. Elvin J, Tuninetti A, Escudero P. Non-Native Dialect Matters: The Perception of European and Brazilian Portuguese Vowels by Californian English Monolinguals and Spanish-English Bilinguals. Languages, v. 3, n. 3, pp. 1-18, 2018. https://www.mdpi.com/2226-471X/3/3/37

23. Escudero P, Boersma P, Rauber A, Bion RAH. A cross-dialect acoustic description of vowels: Brazilian and European Portuguese. J Acoust Soc Am, v. 126, n. 3, pp. 1379-1393, 2009. https://asa.scitation.org/doi/10.1121/1.3180321

24. Evdokimova V, Kocharov D, Skrelin P. Metod postroeniia formantnykh kartin dlia issledovaniia foneticheskikh kharakteristik glasnykh [Method for constructing formants for studying phonetic characteristics of vowels]. Tr. SPIIRAN, v. 19, n. 2, pp. 302-329, 2020. https://doi.org/10.15622/sp.2020.19.2.3

25. Farneda ES. Português língua de acolhimento - cursos de extensão e capacitação para professores de português língua materna: abordagens e práticas. In: Gonçalves Mendes RM. (Ed.) Ensino e Aprendizagem de Línguas Adicionais em Foco. Roosevelt: Boavista Press, 2019. pp. 53-64.

26. Feiden JA, Alves UK, Finger I. $O$ efeito da anterioridade e da altura na identificação das vogais médias altas e médias baixas do Português Brasileiro por falantes de espanhol. Letras de Hoje, v. 49, pp. 85-94, 2014. http://revistaseletronicas.pucrs.br/ojs/index.php/fale/article/view/14715

27. Flege J. Second-language Speech Learning: Theory, Findings, and Problems. In: Strange W (Ed.) Speech Perception and Linguistic Experience: Issues in Cross-language Research. Timonium, MD: York Press, 1995. pp. 229-273.

28. Flege J. Language contact in bilingualism: Phonetic system interactions. In: Cole J, Hualde JI. (Eds.) Papers in Laboratory Phonology 9, Berlin: Mouton de Gruyter, 2007. pp. 353-382.

29. Flege J, MacKay I. Perceiving vowels in a second language. Studies in second language acquisition, 26, pp. 1-34, 2004.

30. Flege J, MacKay I. What accounts for "age" effects on overall degree of foreign accent? In: Wrembel M, Kul M, Dziubalska-Kolaczyk K. (Eds.) Achievements and perspectives in the acquisition of second language speech: New Sounds 2010. Vol. 2. Bern: Peter Lang, 2011. pp. 65-82.

31. Furtoso VB. Aspectos de formação do professor de Português para Falantes de Outras Línguas. Furtoso VB. (Org.) Formação de professores de Português para Falantes de Outras Línguas. Londrina: Eduel, 2009. pp. 23-46.

32. Head BF, Semenova-Head L. Problemas na aprendizagem da pronúncia portuguesa entre falantes adultos de russo. Cadernos de Comunicação e Linguagem, vol. 2, pp. 13-33, 2010. https://bdigital.ufp.pt/handle/10284/2957

33. IOM World Migration Report 2018, UN, New York, 2018. https://doi.org/10.18356/f45862f3-en

34. Kendall RR. The Perception and Production of Portuguese Mid-Vowels by Native Speakers of American English. Dissertation (Master of Arts) - Department of Spanish and Portuguese, Brigham Young 
The perception of Brazilian Portuguese open and close mid vowels by native Russian speakers

$\begin{array}{lll}\text { University, } & \text { Provo, } & \text { UT, }\end{array}$ https://scholarsarchive.byu.edu/cgi/viewcontent.cgi?article=1004\&context=etd

35. Kuznetsov VI. Vokalizm sviaznoi rechi: eksperimental'noe issledovanie na materiale russkogo iazyka [Vocalism of connected speech: experimental investigation on the material of Russian language. In Russian]. Saint Petersburg, Izd-vo Sankt-Peterburgskogo universiteta, 1997.

36. Laver J, Mackenzie-Beck J. Vocal Profile Analysis Scheme-VPAS [handout]. Edinburgh: Queen Margaret University College, Research Centre, 2007.

37. Lopez APA. Subsídios para o planejamento de cursos de português como língua de acolhimento para imigrantes deslocados forçados no Brasil. Dissertação (Mestrado em Linguística Aplicada) - Faculdade de Letras, Universidade Federal de Minas Gerais, Belo Horizonte, 2016.

38. Machry da Silva S. A produção das vogais tônicas do português (L2) por falantes nativos do espanhol. Revista ORGANON, v. 30, p3. 91-108, 2015. https://seer.ufrgs.br/organon/article/viewFile/52016/34331

39. Massini G. A duração no estudo do acento e do ritmo em português. Dissertação (Mestrado em Linguística) - Universidade Estadual de Campinas, Campinas, 1991.

40. Mileski I. Variação no português de contato com o polonês no Rio Grande do Sul: vogais médias tônicas e pretônicas. Tese (Doutorado em Letras) - Faculdade de Letras da Pontifícia Universidade Católica do Rio Grande do Sul, Porto Alegre, 2017. http://tede2.pucrs.br/tede2/handle/tede/7794

41. Miranda YCC, Lopez APA. Considerações sobre a formação de professores no contexto de ensino de português como língua de acolhimento. In: Freitas Silva M. (Ed.) Língua de Acolhimento: experiências no Brasil e no mundo. Belo Horizonte: Mozaico, 2019. pp. 17-40. http://www.letras.ufmg.br/padrao_cms/documentos/profs/luciane/capa_linguadeacolhimentoEBOOK\%20D EFINITIVO.pdf

42. Mora J, Keidel J, Flege J. Why are the Catalan contrasts between /e/ - / $\varepsilon /$ and $/ \mathrm{J} / \mathrm{I} / \mathrm{J} /$ so difficult for even early Spanish-Catalan bilinguals to perceive? In: Wrembel M, Kul M, Dziubalska-Kolaczyk K. (Eds.) Achievements and perspectives in the acquisition of second language speech: New Sounds 2010. V. 2. Bern: Peter Lang, 2011. pp. 183-193.

43. Mora J, Keidel J, Flege J. Effects of Spanish use on the production of Catalan vowels by early SpanishCatalan bilinguals. In: Romero J, Riera M. (Eds.) The Phonetics-Phonology Interface: Representations and methodologies. Amsterdam: John Benjamins, 2015. pp. 33 - 53.

44. Oliveira DM de. A importância da institucionalização do ensino de português para estrangeiros para a internacionalização das universidades brasileiras: uma proposta de curso em contexto acadêmico. In: II Congresso Internacional de Ensino da Universidade Estadual do Norte do Paraná. Cornélio Procópio, PR: Universidade Estadual do Norte do Paraná, 2019. pp. 80-89.

45. Ordin M. Palatalization and intrinsic prosodic vowel features in Russian. Lang Speech., v. 54, pp. 547568, 2011. https://doi.org/10.1177/0023830911404962

46. Pereyron L, Alves UK. Descrição acústica das vogais tônicas do espanhol rioplatense e de uma variedade do português do sul do brasil de monolíngues e bilíngues: uma discussão dinâmica sobre desenvolvimento $\begin{array}{lllllll}\text { linguístico. Revista Linguística (Online), } & \text { v. } & 35, & \text { pp. } & 103-127,\end{array}$ https://lume.ufrgs.br/handle/10183/196695

47. Polivanov ED. A percepção dos son de uma língua estrangeira. In: Toledo D. (Org.) Círculo Linguístico de Praga: estruturalismo e semiologia. Porto Alerge: Editora Globo, 1978 [1931]. pp. 113-128.

48. Ribeiro AA. (Org.). Português do brasil para estrangeiros: políticas, formação, descrição. Campinas, SP: Pontes Editores, 2018.

49. Ruseishvili, S. Ser russo em São Paulo. Os imigrantes russos e a reformulação de identidade após a Revolução Bolchevique de 1917. Tese (Doutorado em Sociologia) - Faculdade de Filosofia, Letras e Ciências Humanas, Universidade de São Paulo, São Paulo, 2016. https://teses.usp.br/teses/disponiveis/8/8132/tde-13022017-124015/pt-br.php 
50. Sant'Anna MR de. A pronúncia das consoantes inglesas em final de vocábulo por falantes brasileiros. Tese (Doutorado em Letras) - Faculdade de Filosofia, Letras e Ciências Humanas, Universidade de São Paulo, São Paulo, 2008. https://www.teses.usp.br/teses/disponiveis/8/8139/tde-03022009113509/publico/TESE_MAGALI_ROSA_SANTANNA.pdf

51. Sappok K, Kasatkin L, Kasatkina R. Novye nabljudenija nad govorom d. Leka [New observations on the dialect speech of Leka]. Die Welt der Slaven, n. 38, pp. 89-101, 1993.

52. Scherba LV. Iazykovaia sistema i rechevaia dejatel'nost' [The language system and speech. In Russian]. Leningrad: Nauka, 1974.

53. Simões ARM, Kelm OR. O processo de aquisição das vogais semi-abertas "é, ó" / $\varepsilon$, o / do Portugues Brasileiro como lingua estrangeira. Hispania: A Journal Devoted to the Interests of the Teaching of Spanish and Portuguese, v. 74, 654-665, 1991. http://hdl.handle.net/1808/17958

54. Stangroom, J. One-Way ANOVA Calculator. Social Science Statistics. https://www.socscistatistics.com/tests/anova/default2.aspx (accessed August 13, 2020).

55. Stangroom, J. The Kolmogorov-Smirnov Test of Normality Calculator. Social Science Statistics. https://www.socscistatistics.com/tests/kolmogorov/default.aspx (accessed August 13, 2020).

56. Stangroom, J. Spearman's Rho Calculator. Social Science Statistics. https://www.socscistatistics.com/tests/spearman/default.aspx (accessed August 13, 2020).

57. Stangroom, J. T-Test Calculator. Social Science Statistics. https://www.socscistatistics.com/tests/studentttest/default.aspx (accessed August 13, 2020).

58. Smirnova Henriques A, Madureira S. Russian accent in Brazilian Portuguese affects the perception of the voice pleasantness by Brazilians. In: I Encontro Internacional de Estudos Poloneses. Curitiba: Universidade Federal do Paraná, 2019. p. 66. https://www.polonesufpr10anos.com.br/caderno-de-resumos

59. Smirnova Henriques A, de Souza Fontes MA, Skrelin PA, Kachkovskaia TV, Ruseishvili S, Borrego MC, Zuleta PPB, Piccolotto Ferreira L, Madureira S. Russian immigrants in Brazil: to understand, to be understood. In press, Cadernos de Linguística.

60. Sorokin VN, Leonov AS, Makarov IS. Ustojchivost' otsenok formantnykh chastot [Stability of estimation of formant frequencies]. Rechevye technologii, 1, p. 3-21, 2009.

61. Trubetzkoy N. Principles of Phonology. Translated by Baltaxe CA. Berkeley: University of California Press, 1969 [1939].

62. Vinokur TG. Drevnerusskiy iazyk [Old Russian language]. Moscow: Lenand, 2016.

63. Volskaya N, Kocharov D, Evgrafova K, Glotova O, Evdokimova V, Skrelin P. CORPRES - Corpus of Russian Professionally Read Speech. Lecture Notes in Computer Science, v. 6231, pp. 392-399, 2010.

64. Vitoriano de Almeida K, Borrego MC, Gobbo R, Basílio M, Smirnova Henriques A, Zuleta PPB, Ruseishvili S, Piccolotto Ferreira L. Produção oral de falantes russos que aprendem português brasileiro. In: XXVI Congresso Brasileiro de Fonoaudiologia. Curitiba: Universidade Tuiuti do Paraná, 2018. p. 10365. https://www.sbfa.org.br/portal/anais2018/trabalhos_select.php?tt=Busca\&id_artigo=10365 